\title{
E-demokracija v Sloveniji: analiza strategij E-uprave
}

UDK: 004.738.5:35(497.4)(045)

\author{
Andraž Bobovnik \\ andraz.bobovnik@gov.si
}

\section{IZVLEČEK}

Razvite zahodne demokracije v zadnjih letih e-demokraciji posvečajo vse več pozornosti, Slovenija pa v primerjavi z njimi vse bolj zaostaja. Eden izmed razlogov bi lahko bil tudi ta, da nimamo strateškega dokumenta, ki bi opredeljeval temeljna področja in mejnike prihodnjega razvoja e-demokracije pri nas. Ključen dokument na tem področju pri nas je tako Strategija e-uprave Republike Slovenije za obdobje 2006 do 2010. V prihodnosti pa bo to vlogo kot kaže igrala Strategija razvoja elektronskega poslovanja ter izmenjave podatkov iz uradnih evidenc. Namen članka je pokazati, da ne prva in ne druga ne izpolnjujeta niti najosnovnejših pogojev za uspešen razvoj e-demokracije in bo zato potrebna predstavitev specifičnega dokumenta oz. strategije.

Ključne besede: e-demokracija, e-uprava, e-participacija.

JEL : H11

\section{Uvod}

Informacijska družba oz. razvoj le-te v razvitem svetu ni več vprašanje. Informacijska revolucija, kot nekateri tudi imenujejo ta prehod, prinaša s seboj daljnosežne in globalne posledice. Alternative ni. Trenutno se informacijska družba izkazuje kot edina smer in pot v prihodnost. Sodobne informacijskokomunikacijske tehnologije (IKT), ki vse bolj in bolj prodirajo $\vee$ vsakdan vsakega izmed nas, so znanilke in obenem tudi glavne nosilke teh sprememb. Nove tehnologije pa ne spreminjajo samo delovanja družbe, temveč tudi njene osnovne strukture. Informacijska družba tako s seboj prinaša korenito družbeno in politično transformacijo. 
Andraž Bobovnik

E-demokracija v Sloveniji: analiza strategij E-uprave

Novo družbenopolitično realnost bi lahko predstavljala elektronska demokracija (v nadaljevanju e-demokracija). $V$ e-demokraciji nekateri vidijo rešitev vseh sodobnih demokratičnih problemov, na določenih področjih pa bi lahko bila tudi odgovor na pomanjkljivosti družbenopolitičnih struktur $\vee$ razvitih državah zahodnega sveta, ki jih je izpostavila trenutna gospodarska kriza. Konkretne družbenopolitične institucije, natančneje javna uprava, so se na pojav edemokracije odzvale $z$ informatizacijo in digitalizacijo lastnih delovnih procesov - z e-upravo. Ta se pogosto predstavlja kot najpomembnejši vidik elektronske demokracije. Kljub temu pa si nekatere bolj razvite države že dalj časa prizadevajo tudi za razvoj drugih področij e-demokracije. $V$ skladu s tem so predstavile tudi nove strateške dokumente, ki naj bi usmerjali ta razvoj $\vee$ prihodnosti. V Sloveniji takega dokumenta na področju e-demokracije žal še nimamo.

Osrednji dokument na področju e-demokracije $\vee$ Sloveniji trenutno predstavlja Strategija e-uprave Republike Slovenije za obdobje 2006 do 2010 (SEP2010). V prihodnosti pa bo to kot kaže Strategija razvoja elektronskega poslovanja ter izmenjave podatkov iz uradnih evidenc (SREP). Razvoj e-demokracije $v$ Sloveniji bo tako očitno vsaj v bližnji prihodnosti popolnoma povezan z razvojem e-uprave. Kratki opredelitvi osnovnih pojmov zato $v$ nadaljevanju prispevka sledita analiza Strategije e-uprave Republike Slovenije za obdobje 2006 do 2010 in komentar Strategije razvoja elektronskega poslovanja ter izmenjave podatkov iz uradnih evidenc z vidika e-demokracije. Namen prispevka je poudariti (ne)urejenost področja e-demokracije $\vee$ Sloveniji in potrditi tezo, da Republika Slovenija za doseganje zastavljenih ciljev in ustrezen razvoj področja e-demokracije potrebuje specifičen dokument oz. strategijo, saj Strategija e-uprave Republike Slovenije za obdobje 2006 do 2010 in Strategija razvoja elektronskega poslovanja ter izmenjave podatkov iz uradnih evidenc ne izpolnjujeta niti najosnovnejših pogojev za uspešen razvoj e-demokracije.

\section{E-demokracija}

\subsection{Opredelitev e-demokracije}

Na začetku poglavja o elektronski demokraciji je najprej treba razčistiti uporabo različnih poimenovanj za različne vidike enotnega predmeta preučevanja. Uporabo sodobnih tehnologij $\vee$ demokratičnih praksah obstoječih 


\section{E-demokracija v Sloveniji: analiza stratraž Bobovnik}

političnih sistemov nekateri avtorji opredelijo s pojmom e-demokracija (edemocracy) (Oblak, 2002), spet drugi dajejo prednost pojmu digitalna demokracija (digital democracy) (Hacker \& van Dijk, 2000) ali virtualna demokracija (virtual democracy) (Hagen, 1996). Poudariti je treba, da se med temi pojmovanji določene razlike pojavljajo le pri poudarkih avtorjev na določenem vidiku elektronske demokracije, v osnovi pa so njihova izhodišča zelo podobna. Pri uporabi pojmov teledemokracija (teledemocracy), kibernetska demokracija (cyberdemocracy) in elektronska demokratizacija (electronic democratization) pa moramo biti bolj pozorni, saj ti pojmi zaznamujejo različne koncepte na področju elektronske demokracije, zato jih je treba uporabljati v skladu s teoretičnimi izhodišči avtorjev'. Sam bom tudi v nadaljevanju uporabljal izraz e-demokracija, tako zaradi splošnosti in primernosti glede na obravnavano temo, kot tudi zaradi pozitivne konotacije tehnološkega in človeškega napredka predpone "e-« v vsakdanjem družbenem življenju.

Steven Clift o e-demokraciji pravi, da gre za vprašanje, kako lahko internet okrepi obstoječe demokratične procese in poveča možnosti za interakcijo posameznikov in skupin z odločevalci in le-tem omogoči, da dobijo več podatkov in informacij (input) o željah in zahtevah prvih. Za internet meni, da edemokraciji omogoča nove možnosti komunikacije in participacije med državljani in državo (Clift v Riley, 2003, str. 11). Hacker in van Dijk pa digitalno demokracijo opredelita kot izvajanje demokratičnih praks brez omejitev prostora in časa ter katerih koli drugih fizičnih omejitev s pomočjo informacijskokomunikacijskih tehnologij in računalniškega komuniciranja. Te nove demokratične prakse pomenijo dodatek oz. nadgradnjo že poznanih obstoječih analognih demokratičnih praks (Hacker \& van Dijk, 2000).

Pomemben del e-demokracije predstavlja vidik demokratičnih institucij, procesov odločanja, predstavljanja interesov organiziranosti itn. Oblakova o tem zapiše: "Sodeč po dosedanjih izkušnjah elektronska demokracija ni projekt, ki bi tekmoval z obstoječimi demokratičnimi sistemi, temveč je kompatibilen z mnogimi različnimi in raznorodnimi obstoječimi institucijami, pri čemer je $v$ praksi najpogosteje zastavljen tako, da bi popravil njihove očitne pomanjkljivosti. « (Oblak, 2002, str. 158). E-demokracija naj torej ne bi bila nova vrsta ali oblika demokracije, temveč naj bi bila zgolj prilagoditev že obstoječih form novim okoliščinam.

1 Za podrobnejšo opredelitev navedenih pojmov glej: Hagen, M. (1996). A Road to Electronic Democracy? Giessen: Justus-Liebig University of Giessen. 
Andraž Bobovnik

E-demokracija v Sloveniji: analiza strategij E-uprave

Sodobne tehnologije naj bi teorijam participativne demokracije končno omogočile, da svoje organizacijske in institucionalne ureditve prenesejo iz majhnih idealnotipskih skupnosti na velike kompleksne nacionalne države (Zittel v Gibson et al, 2004, str. 75). Andrej Lukšič ugotavlja, da predstavniška oblika demokracije kot koncept družbenega organiziranja, osnovanega na razumevanju politike $\vee$ 18. in 19. st., ni več kos sodobnim družbenopolitičnim problemom. Kot rešitev izpostavi uporabo in izkoriščanje potencialov sodobnih tehnologij oz. uvajanje prvin e-demokracije. Kljub temu pa opozarja, da trenutni razvoj in uvajanje e-demokracije $v$ zahodnih demokracijah favorizirata le določene vidike emancipatornih potencialov, drugi pa ostajajo neizkoriščeni (Lukšič \& Oblak, 2003, str 4).

\subsection{Elektronska politična participacija}

E-participacija je eden izmed najpomembnejših vidikov e-demokracije. Eparticipacijo številni politični akterji vidijo kot rešitelja vedno bolj perečega problema demokratičnega deficita na vseh ravneh političnega sistema. Realnost eparticipacije pa je nekoliko drugačna. E-participacija najverjetneje ne pomeni končne rešitve za zdajšnjo nizko raven politične participacije državljanov. Gotovo pa lahko e-participacija kot eden pomembnejših vidikov politične participacije pripomore k odpravljanju nekaterih ključnih problemov demokratičnega deficita v predstavniških demokracijah (Oblak, 2000, str. 121).

Elektronska participacija vključuje e-sodelovanje in e-soodločanje državljanov $\vee$ procesu vladnega sprejemanja politik, $\vee$ zakonodajnem postopku, pri nadzoru izvoljenih predstavnikov ter $\vee$ postopku oblikovanja politik $\vee$ političnih strankah in organizacijah civilne družbe (e-Envoy, 2002, str. 23). Organizacija za gospodarsko sodelovanje in razvoj (OECD) je razvila tristopenjski model vključevanja državljanov v politično odločanje oz. razvoja politične e-participacije (Coleman \& Gotze, 2001, str. 13):

- Informiranje: Gre za enosmeren odnos med državo in državljani, v katerem ti aktivno in pasivno pridobivajo informacije, ki so osnova in pogoj za politično participacijo, primer so uradne spletne strani.

- Posvetovanje: Gre za dvosmeren odnos med državo in državljani, v katerem država pridobiva povratne informacije o mnenju državljanov. Država opredeli problematiko, o kateri želi izvedeti mnenja državljanov, primer so spletni posveti o zakonskih predlogih. 


\section{Andraž Bobovnik
E-demokracija v Sloveniji: analiza strategij E-uprave}

- Aktivna participacija: Gre za partnerski odnos med državo in državljanom, v katerem državljan aktivno sodeluje pri oblikovanju javnih politik in odločanju o njih. Čeprav končno odločitev še vedno sprejme država, je državljan $v$ tem odnosu prepoznan kot pomemben akter na področju pobude in oblikovanja javnih politik ter tudi odločanja o njih.

Spletni portal E-demokracija predstavlja naslednjo klasifikacijo orodij eparticipacije (Kvas, 2005):

- E-dostop je najosnovnejše orodje e-participacije in predstavlja pogoj za e-demokracijo.

- E-posvetovanje/e-anketa je orodje preverjanja javnega mnenja, $v$ katerem lahko državljan aktivno izraža svoje mnenje, vendar $v$ omejenem obsegu.

- E-peticija je orodje, s katerim lahko državljani postanejo pobudniki političnega delovanja.

- E-forum omogoča oblikovanje in izmenjavo političnih in vseh drugih stališč državljanov.

- E-konzultacija omogoča vključevanje različnih organiziranih ali neorganiziranih skupin in posameznikov, ki imajo možnost komentiranja in oblikovanja političnih odločitev.

- E-referendum omogoča neposredno vključevanje državljanov $v$ odločevalski proces.

- E-glasovanje je digitalizacija volilnega procesa, $v$ katerem lahko državljan s pomočjo sodobnih tehnologij voli svoje politične predstavnike.

- Spletni dnevnik je orodje, ki državljanom nudi možnost individualiziranega izražanja političnih stališč in komentiranja le-teh.

\subsection{E-uprava in e-demokracija}

Vse prepogosto prihaja $v$ vsakdanjih pogovorih, medijih, pa tudi $v$ strokovnih člankih do malomarne in pogosto celo zavajajoče uporabe pojmov e-uprava in e-demokracija. Kot da razlikovanje med tradicionalno demokracijo in javno upravo ne bi bilo dovolj jasno, da bi to lahko prenesli tudi na raven informacijske družbe. Ponovno poglejmo opredelitvi demokracije in javne uprave. Po Slovarju 
Andraž Bobovnik

E-demokracija v Sloveniji: analiza strategij E-uprave

slovenskega knjižnega jezika na spletu (Slovar slovenskega knjižnega jezika, 2000) je:

- Demokracija: "politična ureditev z vladavino večine, ki varuje osebne in politične pravice vseh državljanov«.

- Javna uprava: „odločanje o javnih zadevah; sistem organov, ki odločajo o javnih zadevah «.

Kot lahko vidimo, $v$ primeru demokracije govorimo o tipu politične ureditve, $v$ primeru javne uprave pa o upravnem sistemu, ki podpira določen način vladanja.

Pri vprašanju e-demokracije in e-uprave je stvar bolj ali manj enaka. Predpona "e-« nakazuje le določeno prevladujočo obliko ali medij delovanja demokracije in javne uprave. E-demokracijo in e-upravo lahko tako opredelimo kot:

- E-demokracija: "pomeni vsak demokratični politični sistem, v katerem so računalniki in računalniška omrežja uporabljeni za izvajanje ključnih funkcij demokratičnega procesa: informiranje in komuniciranje, artikulacija in združevanje interesov ter politično odločanje (tako posvetovanje kot glasovanje) « (Hagen, 1996, str. 64).

- E-uprava: "gre za intenzivno uvajanje interneta in elektronskega poslovanja $v$ javno upravo, med upravnimi organi $v$ upravi, navzven $z$ občani, podjetji in drugimi organizacijami« (Silič v Cimolini, 2003, str. 17).

E-uprava je sicer pomemben element e-demokracije in na tem področju vsekakor pomeni tudi pomembno gonilno silo, nikakor pa teh dveh pojmov ne moremo uporabljati kot sopomenki (Clift, 2004). Gre za različna teoretična in praktična koncepta.

\section{Strategija e-uprave Republike Slovenije za obdobje 2006 do 2010}

\subsection{Predstavitev}

Vlada RS je na seji 20. aprila 2006 sprejela Strategijo e-uprave Republike Slovenije za obdobje 2006 do 2010 (SEP-2010). Namen strategije je določitev 


\section{Andraž Bobovnik
E-demokracija v Sloveniji: analiza strategij E-uprave}

načina in ciljev za nadaljnje uresničevanje dejavnosti e-uprave. Strategija predstavlja vizijo e-uprave, vplive drugih domačih in tujih strategij ter programov na tem področju, oceno stanja za preteklo obdobje, strateške usmeritve in cilje do leta 2010 ter pogoje za izvedbo zastavljene strategije. Poudarek je na zadovoljstvu uporabnikov, racionalizaciji poslovanja uprave in sodobnih elektronskih storitvah, ki bodo omogočile večjo kakovost življenja in lažje poslovanje z organi javne uprave (Ministrstvo za javno upravo RS, 2006).

Nastanek SEP-2010 sega $\vee$ marec 2005. Takrat je projektna skupina na Ministrstvu za javno upravo RS začela snovati vizije in strateške cilje e-uprave ter nadaljevala pripravo drugih ključnih vsebin strategije. Do konca leta 2005 je bil oblikovan osnutek. 15. februarja 2006 je bil predlog strategije objavljen na spletnih straneh portala E-uprava ter s tem predstavljen širši javnosti. Po javni obravnavi je sledilo medresorsko usklajevanje strategije in oblikovanje končnega dokumenta (Ministrstvo za javno upravo RS, 2006).

\subsection{Potek analize}

Analitični aparat oz. kriterije analize sem razdelil na dva sklopa: akterji in uvajanje SEP-2010. Percepcija akterjev, njihova informiranost in participacija so namreč najpomembnejši vidiki e-demokracije (Hacker \& van Dijk, 2000). Z vidika izvajanja javnih politik pa je gotovo uvajanje tista faza, ki jo vsi vključeni najbolj neposredno občutijo. Kriteriji analize pokrivajo tri od štirih ključnih področij, ki jih poudarjajo evalvacije pobud na področju e-demokracije, to so: obseg participacije, vključenost $v$ odločevalski proces in poglobljenost razprave (Delakorda, 2007). četrto področje - tehnološki vidik, sem izpustil, ker je SEP2010 preveč splošen dokument, da bi omenjal specifične tehnološke rešitve.

$\mathrm{Na}$ področju akterjev je analiza razdeljena na dva sklopa. $V$ prvem se osredotoča na vprašanje, kako SEP-2010 naslavlja ključne akterje, kot državljane ali izključno kot uporabnike storitev - stranke, in na vprašanje informiranosti teh akterjev oz. ali strategija opredeljuje kakršne koli dodatne ali izredne aktivnost na področju informiranja državljanov o predvidenih spremembah $v$ demokratičnih političnih praksah. Drugi sklop analize pa se osredotoča na participacijo akterjev in podrobneje odgovarja na vprašanja, kdo so subjekti participacije, kaj jim strategija prinaša ter kdaj in kako prihaja do njihovega vključevanja.

Na področju uvajanja SEP-2010 je analiza razdeljena $v$ tri sklope in sicer na vprašanja orodij e-demokracije, institucionalnih sprememb in evalvacije strategije. Pri vprašanju orodij e-demokracije je pozornost posvečena predvsem tipom orodij, ki 
Andraž Bobovnik

E-demokracija v Sloveniji: analiza strategij E-uprave

jih strategija omenja. Na področju institucionalnih sprememb se analiza osredotoča na vprašanje, ali strategija te spremembe sploh uvaja. Pri vprašanju evalvacije SEP-2010 pa se analiza osredotoča na idejo vzpostavitve krovnega organa, ki bi nadziral izvajanje strategije, in doseganje zastavljenih ciljev ter nadaljevanje dela $\vee$ prihodnosti.

\subsection{Predstavitev rezultatov}

\subsubsection{Akterji}

Razlikovanje med državljani in strankami je, kadar govorimo o razvoju euprave in še posebej e-demokracije, zelo pomembno, saj nakazuje neposredne odnose med udeleženci komunikacijskih procesov. Ko govorimo o strankah, gre za razmerje ponudnik storitev - stranka, ki pa ga nikakor ne moremo enačiti s sodobnim razmerjem med državljanom in oblastjo. $\vee$ prvem primeru bi tako lahko govorili o tržnem modelu političnega komuniciranja, za katerega je značilen bolj ali manj enosmeren pretok informacij od centra proti uporabnikom, $v$ drugem primeru pa o internetnem modelu komuniciranja, za katerega je značilna odprtost in dvosmernost pretoka informacij ter konzultacij (Hacker \& van Dijk, 2000, str. 49). V Strategiji e-uprave Republike Slovenije za obdobje 2006 do 2010 prevladuje uporaba pojma državljani nad uporabo pojma stranke, kar z gotovostjo širi možnosti komunikacije.

Informiranost državljanov o novih storitvah in možnostih, ki jih prinašata euprava in e-demokracija, je zelo pomembna za nadaljnjo uporabo teh storitev. Vzpostavljanje storitev, ki jih državljani zaradi pomanjkljive informiranosti ne bi uporabljali, je nesmiselno. Zato mora razvoju novih storitev slediti njihovo ustrezno oglaševanje in informiranje državljanov o novih možnostih. Promocijo storitev in tehnologij ter informiranje državljanov SEP-2010 obravnava precej splošno. Del bremena tako prenaša na ponudnike tehnologij in storitev, neposredno pa opredeli le nove programe usposabljanja uporabnikov e-storitev, ki naj bi vključevali organizacijo tečajev in javnih predstavitev novosti.

Akcijski načrt razvoja e-uprave v Evropski uniji i2010, Načrt za inkluzivno e-upravo, (A roadmap for Inclusive eGovernment), vključenosti marginaliziranih in družbeno deprivilegiranih skupin $\vee$ e-upravo namenja posebno pozornost. Enake možnosti naj bi bile prednostna naloga prihodnjega razvoja e-uprave, ki naj bi bila v prihodnosti sestavni del pravičnejše informacijske družbe (Evropska komisija, 2006, str. 8). SEP-2010 v tem pogledu akterje dojema $v$ prvi vrsti kot 


\section{E-demokracija v Sloveniji: analizaž Bobovnik}

posameznike, uporabnike e-storitev. $\vee$ skladu $s$ tem jih nato deli $v$ tri skupine: državljane, pravne osebe oz. poslovne subjekte in zaposlene $\vee$ javni upravi. Strategija le na treh mestih bežno omeni deprivilegirane in marginalizirane posameznike in družbene skupine, pa še to le na deklarativni ravni; ko navaja strateške cilje, se zavzame za zmanjševanje digitalnega razkoraka $v$ prihodnosti in prilagoditev spletnega portala E-uprava sodobnim standardom dostopa. V povezavi z digitalnim razkorakom se $v$ teoriji in praksi pogosto pojavlja tudi vprašanje dostopa do tehnologij oz. ustrezne infrastrukture in potrebnega znanja. Internet in z njim povezane računalniške tehnologije so namreč $v$ večini primerov še vedno, kljub eksponentni rasti $\vee$ zadnjih letih, omejene na družbene, gospodarske in izobrazbene elite (Lock v Hague \& Loader, 1999, str. 215). $\vee$ skladu $s$ temi ugotovitvami je pri razvoju e-uprave in e-demokracije $\vee$ prihodnosti tema področjema treba posvetiti posebno pozornost. SEP-2010 se zavzema za nadaljnji infrastrukturni razvoj informacijske družbe z različnimi pristopi, kot so npr. javne internetne točke, ter za usposabljanje uporabnikov estoritev in vzpostavitev kontaktnega centra za pomoč uporabnikom.

Ted Becker ugotavlja, da bi morali biti državljani v resničnih demokracijah, še posebej pa $\vee$ njihovih elektronskih variacijah, vključeni $v$ vseh fazah demokratičnega procesa oblikovanja in izvajanja določene javne politike. Po Beckerju so te faze: 1. opredelitev problema oz. oblikovanje dnevnega reda, 2. oblikovanje predloga, 3. sprejem odločitve in 4. uvajanje politike. Možnost sodelovanja v celotnem procesu sprejemanja in izvajanja javnih politik je namreč za državljane demokratični institut samoodločanja (Becker $\vee$ Hagen, 1996). Strategija euprave Republike Slovenije za obdobje 2006 do 2010 v določeni meri predpostavlja participacijo državljanov zgolj $\vee$ prvih dveh fazah oblikovanja in izvajanja javnih politik. $\vee$ teh dveh fazah pa je vloga državljanov omejena zgolj na informiranje in posvetovanje.

\subsubsection{Uvajanje}

E-orodja politične participacije so temelj e-participacije in posredno edemokracije. Razvitost področja elektronske politične participacije kaže na razvitost področja e-demokracije. Največkrat se $v$ teoriji pojavlja delitev na informacijska, komunikacijska in odločevalska orodja. $V$ prvo skupino uvrščamo edostop in spletne oglasne deske; $v$ drugo skupino uvrščamo e-posvetovanja, eankete, e-peticije, e-forume, politične spletne dnevnike in spletne klepetalnice; $\checkmark$ tretjo skupino pa uvrščamo e-glasovanje oz. e-volitve, e-referendum in e-seje vlade (Delakorda, 2006). Strategija e-uprave Republike Slovenije za obdobje 
Andraž Bobovnik

E-demokracija v Sloveniji: analiza strategij E-uprave

2006 do 2010 našteva informacijska in komunikacijska orodja z namenom učinkovitejšega posredovanja informacij od državljanov $k$ državi ter omenja možne informacijske rešitve $v$ prihodnosti, med katerimi so se znašla tako informacijska in komunikacijska kot tudi odločevalska orodja.

Rachel Gibson ugotavlja, da bodo eksperimentiranje, inovacije in razvoj na področju e-demokracije $v$ večini primerov neogibno potekali znotraj že določenih institucionalnih ureditev in procesov. Charles Raab in Christine Bellamey te ideje razvijata naprej, ko ugotavljata, da bodo te institucije zaradi njihove naraščajoče kompleksnosti prisiljene prilagoditi svoje delo novim okoliščinam, $\vee$ katerih bodo pomembno vlogo igrale sodobne informacijsko-komunikacijske tehnologije (Gibson et al, 2004, str. 1). SEP-2010 z vidika e-demokracije dejansko ne predvideva nikakršnih institucionalnih ali delovno-procesnih sprememb, ki bi presegale uvajanje določenih sodobnih tehnologij (digitalna potrdila), s katerimi bi bilo $v$ prihodnosti mogoče vzpostaviti specifične mehanizme e-demokracije; česar pa strategija ne predvideva. Javna politika mora že $v$ svoji zasnovi imeti opredeljene kontrolne mehanizme, ki bodo pozneje ključ do vedenja, ali je bila določena javna politika uspešna ali ne. Ti kontrolni mehanizmi $\vee$ različnih pojavnih oblikah pa $\vee$ določeni meri tudi zagotavljajo nadaljevanje javne politike na določenem področju oz. ustrezne spremembe le-te, če se izkaže za neuspešno (Hogwood \& Gunn 1984, str. 3). Strategija e-uprave Republike Slovenije za obdobje 2006 do 2010 na področju monitoringa in evalvacije nadaljuje delo Strategije e-poslovanja $\vee$ javni upravi Republike Slovenije za obdobje 2001 do 2004. V poglavju Izvajanje strategije e-uprave $v$ različnih podpoglavjih temeljito opredeli in razčleni sistem delovanja, nadzora in ukrepanja ter razdeli pristojnosti in odgovornosti za poročanje $v$ povezavi z izvajanjem SEP-2010.

\section{Strategija razvoja elektronskega poslovanja ter izmenjave podatkov iz uradnih evidenc}

\subsection{Predstavitev}

Vlada Republike Slovenije je na svoji 34. redni seji 2. julija 2009 obravnavala in sprejela Strategijo razvoja elektronskega poslovanja ter izmenjave podatkov iz uradnih evidenc (SREP). Namen nove strategije na področju e-uprave 


\section{E-demokracija v Sloveniji: analizaž Bobovnik}

je »določitev okvira in ciljev za nadaljnje uresničevanje novih in že zastavljenih dejavnosti razvoja elektronskega poslovanja v javni upravi« (SREP, 2009, str. 8). Želeli ali ne, so z novo strategijo razvoja e-uprave odločevalci ponovno neposredno posegli $\vee$ razvoj e-demokracije $\vee$ Sloveniji. Zaradi odsotnosti specifičnega dokumenta, ki bi neposredno usmerjal razvoj e-demokracije $v$ Sloveniji, se le-ta namreč posredno oblikuje in določa z dokumenti, ki so namenjeni razvoju edemokraciji sorodnih področij najpogosteje e-uprave.

Prvi osnutek Strategije razvoja elektronskega poslovanja ter izmenjave podatkov iz uradnih evidenc je projektna skupina na Ministrstvu za javno upravo izdelala na začetku februarja 2009. Po določenih popravkih in prilagoditvah osnutka je z obravnavo le-tega konec meseca februarja pričela delovna skupina za izdelavo Strategije razvoja informacijske tehnologije in elektronskih storitev (SRITES). Ta je do 24. marca 2009 pripravila Delovno različico 10 SREP, ki je bila 22. aprila 2009 podana $v$ javno razpravo širši javnosti na spletnem portalu E-uprava.

\subsection{Komentar}

E-demokracija je $\vee$ Strategiji razvoja elektronskega poslovanja ter izmenjave podatkov iz uradnih evidenc omenjena le štirikrat. Nikoli kot osrednji pojem. Elektronske demokracije tako SREP ne prepoznava kot bistveni del razvoja informacijske družbe $v$ Sloveniji oz. kot enega izmed temeljnih ciljev le-te. Kljub temu, da strategija izhaja iz domačih in tujih dokumentov (Strategija e-uprave Republike Slovenije za obdobje 2006 do 2010, Strategija razvoja informacijske družbe v Sloveniji, i2010 Strategija informacijske družbe EU idr.), katerih cilj so tudi določene spremembe na družbenopolitičnem področju, SREP le-teh ne zasleduje. E-demokracija kot eden osrednjih pojmov informacijske družbe tako ostaja izven konteksta strategije razvoja elektronskega poslovanja ter izmenjave podatkov iz uradnih evidenc.

Glede na vsebinsko odsotnost e-demokracije $\vee$ SREP, $\vee$ primerjavi s SEP2010, je težko oceniti vpliv le-te na prihodnji razvoj e-demokracije $\vee$ Sloveniji. Analitični aparat, zastavljen za analizo Strategije e-uprave Republike Slovenije za obdobje 2006 do 2010, je za analizo Strategije razvoja elektronskega poslovanja ter izmenjave podatkov iz uradnih evidenc neustrezen. Kljub temu, da SREP namenja precejšnjo pozornost vključenosti državljanov, deprivilegiranim skupinam, usposabljanju in izobraževanju posameznikov, premagovanju 
Andraž Bobovnik

E-demokracija v Sloveniji: analiza strategij E-uprave

digitalnega razkoraka ipd, pa se to ne nanaša na razvoj e-demokracije temveč izključno na razvoj e-uprave.

Po eni strani je razumljivo, da se relativno tehnokratski dokument na področju razvoja e-uprave neposredno ne ukvarja s splošnejšimi problemi edemokracije. Po drugi strani pa bi pričakovali, glede na odsotnost specifičnejših dokumentov na tem področju, da bi SREP določeno pozornost namenil tudi razvoju tega področja. E-demokracije tako npr. ne najdemo niti v podpoglavju priloge, ki je namenjeno razvoju informacijske družbe. S stališča razvoja resnične informacijske družbe in e-demokracije, kot enega njenih osrednjih elementov, tako SREP z gotovostjo predstavlja korak nazaj od že zastavljenih ciljev v SEP-2010.

\section{Sklep}

Čeprav sta Strategija e-uprave Republike Slovenije za obdobje 2006 do 2010 in Strategija razvoja elektronskega poslovanja ter izmenjave podatkov iz uradnih evidenc predvsem strateška dokumenta na področju razvoja e-uprave, zaradi odsotnosti kakršnega koli drugega specifičnejšega dokumenta na tem področju neogibno vplivata tudi na prihodnji razvoj e-demokracije v Sloveniji. V SEP-2010 v poglavju Usmeritve in cilji do leta 2010 celo piše: „Država Slovenija je (leta 2010) med 10-imi najbolj razvitimi državami na področju e-demokracije na svetu« (SEP-2010, 2006, str. 16). SREP po drugi strani e-demokracijo komajda omeni.

Indeks e-participacije $v$ poročilu Združenih narodov o splošnem stanju euprave v 192 državah za leto 2007 Slovenijo uvršča na 60. mesto, enako poročilo za leto 2005 jo je uvrstilo na 46. mesto ${ }^{2}$. Razvoj e-demokracije $\vee$ Sloveniji je $v$ zadnjih letih očitno zaostal za razvojem $v$ drugih državah po svetu. Čeprav Slovenijo indeksi, ki merijo izključno razvitost e-uprave, uvrščajo razmeroma visoko, pa Slovenija na teh in podobnih lestvicah izrazito pade, ko gre za merjenje e-participacije kot enega izmed ključnih vidikov e-demokracije (Lukšič \& Delakorda, 2006, str. 2). Slovenija počasi zaostaja tudi po splošni razvitosti na področju informacijskih in komunikacijskih tehnologij. Po raziskavi

2 United Nations E-government Knowledge Base (2007). e-Government Readiness report 2007. New York: United Nations E-government Knowledge Base. 


\section{Andraž Bobovnik
E-demokracija v Sloveniji: analiza strategij E-uprave}

Mednarodnega telekomunikacijskega združenja, objavljeni letos spomladi, je Slovenija z 22. padla na 28 mesto. ${ }^{3}$ Cilje SEP-2010 bo tako zelo težko doseči.

Analiza Strategije e-uprave Republike Slovenije za obdobje 2006 do 2010 nam pokaže, da strategija ne predvideva dodatnih aktivnosti na področju informiranja državljanov o možnostih e-demokracije; se ne posveča marginaliziranim in deprivilegiranim posameznikom in skupinam; ne konkretizira pobud na področju zmanjševanja digitalnega razkoraka (dostop, infrastruktura, znanje); predpostavlja sodelovanje državljanov le $v$ prvih dveh fazah oblikovanja in izvajanja javnih politik (oblikovanje dnevnega reda in oblikovanje predloga); participacijo državljanov omejuje na informiranje in posvetovanje; se le bežno dotakne orodij e-demokracije; novim institucionalnim in procesnim pristopom in oblikam e-demokracije pa ne posveča nobene pozornosti. SEP-2010 tako ne izpolnjuje večine $v$ analizi zastavljenih kriterijev na področju e-demokracije.

Strategija razvoja elektronskega poslovanja ter izmenjave podatkov iz uradnih evidenc gre $v$ kontekstu e-demokracije še korak nazaj. E-demokracije, kot pomembnega, če ne kar osrednjega dela razvoja informacijske družbe, $v$ strategiji praktično ne najdemo. Kljub določenemu napredku pri premagovanju digitalnega razkoraka, e-demokraciji SREP ne posveča nobene pozornosti. S precejšnjo gotovostjo lahko tako zatrdimo, da Republika Slovenija za doseganje zastavljenih ciljev in ustrezen razvoj področja e-demokracije potrebuje specifičen dokument oz. strategijo, saj Strategija e-uprave Republike Slovenije za obdobje 2006 do 2010 in Strategija razvoja elektronskega poslovanja ter izmenjave podatkov iz uradnih evidenc ne izpolnjujeta niti najosnovnejših pogojev za uspešen razvoj e-demokracije.

Ker e-demokracija gotovo je ena izmed poti $v$ prihodnost in ker jo $v$ številnih pogledih omenjajo kot rešitelja težav, s katerimi se spopadajo sodobne razvite demokracije, bo $\vee$ Sloveniji na tem področju potrebnega še veliko dela (Lukšič \& Oblak, 2003). Ustrezen začetek bi pomenil strateški dokument, ki bi razvoj e-demokracije $\vee$ Sloveniji s pozicije legalističnega modela demokracije, kjer informacijsko-komunikacijske tehnologije rešujejo zgolj vprašanje informiranosti, premaknil $\vee$ smer participativnega modela demokracije, ki bi informiranost državljanov skušal nadgraditi s katerim od orodij, ki bolj spodbujajo participacijo državljanov in deliberacijo v demokratičnih procesih (Lukšič \& Delakorda 2006, str. 4). Taka podlaga bi nato omogočala nadaljnji razvoj odločevalskih orodij e-demokracije in resnično ter vsebinsko participacijo

3 International Telecommunication Union (2009). The ICT Development Index. Geneva: International Telecommunication Union. 


\section{Andraž Bobovnik \\ E-demokracija v Sloveniji: analiza strategij E-uprave}

državljanov v odločevalskih procesih, kar je nenazadnje najverjetneje tudi bistvo same e-demokracije.

Andraž Bobovnik je svetovalec za odnose z javnostmi v kabinetu ministra za delo, družino in socialne zadeve. S sodobnimi informacijsko-komunikacijskimi tehnologijami in njihovim pomenom za razvoj družbe se je soočil med študijem politologije na Fakulteti za družbene vede Univerze v Ljubljani. Teoretične prispevke je dopolnjeval s praktičnim delom pri informacijskih projektih, kot npr. državni portal E-uprava, upravljanje spletnih vsebin in s povezovanjem tradicionalnih veščin odnosov z javnostmi s sodobnimi IKT. Trenutno s študijem nadaljuje na Pravni fakulteti Univerze v Mariboru.

\section{Literatura in viri}

- Anttiroiko, A. \& Becker, T. (2000). Global Perspective on Teledemocracy. Kelevantie: University of Tampere, dostopno na http://www.uta.fi/kuaran/becker.html (maj 2009).

- Birch, A. (2007). The Concepts and Theories of Modern Democracy. Abingdon: Routledge.

- Cimolini, Č. (2003). Elektronska uprava v Sloveniji. Diplomsko delo. Ljubljana: Fakulteta za družbene vede.

- Clift, S. (2004). E-government and Democracy: Representation and Citizen Engagement in the Iformation Age. Minneapolis: Publicus, dostopno na http://www.publicus.net/articles/cliftegovdemocracy.pdf (maj 2009).

- Coleman, S. \& Gøtze, J. (2001). Bowling Together: Online Public Engagement in Policy Deliberation. London: Bowling Together, dostopno na http://www.bowlingtogether.net/bowlingtogether.pdf (maj 2009).

- Delakorda, S. (2002). Elektronska okoljska demokracija. Diplomsko delo. Ljubljana: Fakulteta za družbene vede.

- Delakorda, S. (2006). Kritika osnutka nove Strategije e-uprave RS (SEP-2010). Ljubljana: E-participacija, dostopno na http://www.e-participacija.si/si/refleksije/podeljena-nagradaevropska-edemokracija-2005.html (maj 2009).

- Delakorda, S. (2007). Citizen's Forum: The First Successful eDemocracy Initiative in the republic of Slovenia? Ljubljana: E-participacija, dostopno na http://www.eparticipacija.si/files/citizens_forum-delakorda-echallanges07-final.pdf (maj 2009).

- Delakorda, S, Delakorda, M. \& Lukšič, A. (2006). Sodobna E-uprava: od zadovoljnega uporabnika do vključenega državljana. Ljubljana: E-participacija, dostopno na http://www.e-participacija.si/files/kako_demokratizirati_e-demokracijo.pdf (maj 2009). 


\section{E-demokracija v Sloveniji: analiza strategij E-uprave}

- Evropska komisija (2006): i2010 Action Plan: A Roadmap for Inclusive eGovernment. Bruselj: Evropska komisija, dostopno na http://ec.europa.eu/information_society/activities/egovernment/docs/inclusive_egovernm ent_roadmap.pdf (maj 2009).

- Gibson, R., Rommele, A. \& Ward, S. (2004). Electronic Democracy: Mobilisation, organisation and participation via new ICTs. London: Routledge.

- Hacker, K. \& van Dijk, J. (2000). Digital Democracy: Issues of Theory and Practice. London: Sage.

- Hagen, M. (1996). A Road to Electronic Democracy? Giessen: Justus-Liebig University of Giessen, dostopno na http://www.uni-giessen.de/fb03/vinci/labore/netz/hag_en.htm (april 2009).

- Hague, B. \& Loader, B. (1999). Digital Democracy: Discourse and Decision Making in the Information Age. London: Routledge.

- Hill, K. \& Hughes, J. (1998). Cyberpolitics: Citizen Activism in the Age of Internet. Lanham: Rowman and Littlefeld Publishers.

- Inštitut za slovenski jezik Frana Ramovša ZRC SAZU (2000). Slovar slovenskega knjižnega jezika. Ljubljana: Inštitut za slovenski jezik Frana Ramovša ZRC SAZU, dostopno na http://bos.zrc-sazu.si/sskj.html (junij 2009).

- International Telecommunication Union (2009). The ICT Development Index. Geneva: International Telecommunication Union, dostopno na http://www.itu.int/ITUD/ict/publications/idi/2009/index.html (junij 2009).

- Kvas, B. (2005). Kako? (E-orodja). Ljubljana: E-demokracija, dostopno na http://www.edemokracija.si/?p=6 (maj 2009).

- Lukšič, A. \& Delakorda, S. (2006). Kako demokratizirati e-demokracijo na državnem portalu e-uprave? Ljubljana: E-participacija, dostopno na http://www.eparticipacija.si/files/kako_demokratizirati_e-demokracijo.pdf (maj 2009).

- $\quad$ Lukšič, A. \& Oblak, T. (2003). S poti v digitalno demokracijo. Ljubljana: Fakulteta za družbene vede, dostopno na http://dk.fdv.uni-lj.si/eknjige//Edemokracija.pdf (maj 2009).

- Ministrstvo za javno upravo Republike Slovenije (2006). Strategija e-uprave RS za obdobje od 2006 do 2010 (SEP-2010). Ljubljana: Ministrstvo za javno upravo Republike Slovenije, dostopno na http://e-uprava.gov.si/e-uprava/edemokracijaStran.euprava?pageid=516 (maj 2009).

- Ministrstvo za javno upravo Republike Slovenije (2009). Strategija razvoja elektronskega poslovanja ter izmenjave podatkov iz uradnih evidenc - SREP. Ljubljana: Ministrstvo za javno upravo Republike Slovenije, dostopno na http://www.mju.gov.si/si/zakonodaja_in_dokumenti/predlogi_predpisov/ (junij 2009).

- Mitrovič, S. (2008). Napredna komunikacijska tehnologija je v Sloveniji dobrodošla. Ljubljana: Gfk, dostopno na http://www.gfk.si//novice.php?NID=2010 (april 2009).

- Oblak, T. (2000). Elektronska demokracija in nova prizorišča političnega delovanja. Vregov zbornik 7, 121-131. Ljubljana: Evropski inštitut za komuniciranje in kulturo: Fakulteta za družbene vede. 
Andraž Bobovnik

E-demokracija v Sloveniji: analiza strategij E-uprave

- Oblak, T. (2002). Podobe elektronske demokracije. Teorija in praksa 39 (2), 155-169. Ljubljana: Fakulteta za družbene vede.

- OECD (2003). Promise and Problems of E-democracy: Challenges of Online Citizen Engagements. Pariz: OECD.

- Office of the E-envoy United Kingdom (2002). In the service of democracy: A consultation paper on policy for electronic democracy. London: Office of the E-envoy United Kingdom, dostopno na http://europa.eu.int/idabc/servlets/Doc?id=23060 (maj 2009).

- Riley, T. \& Riley, C. (2003). E-governance to E-democracy: Examining the Evolution. Ottava: Commonwealth Centre for E-Governance, dostopno na http://www.electronicgov.net/pubs/research_papers/tracking03/IntITrackRptJune03no5. pdf (april 2009).

- Trček, F. (1997). Virtualna demokracija - navideznost ali dejanskost? Družboslovne razprave 13 (24/25), 98-117. Ljubljana: Fakulteta za družbene vede, dostopno na http://dk.fdv.uni-lj.si/dr/dr24-25Trcek.PDF (maj 2009).

- United Nations E-government Knowledge Base (2007). E-government Readiness Report 2007. New York: United Nations E-government Knowledge Base, dostopno na http://www2.unpan.org/egovkb/datacenter/CountrySummary.aspx?ddl=7 (maj 2009). 


\section{SUMMARY \\ E- DEMOCRACY IN SLOVENIA: ANALYSIS OF E-ADIMINISTRATION STRATEGIES}

The information society and its development is no longer an issue in the modern world. The information revolution, as some call this transition, brings with it long reaching and global consequences. There is no alternative. At the moment, the information society seems to be the only direction and a way into the future. Modern information communication technologies, which are increasingly present in our every day existence, are the messengers as well as the carriers of those changes. Besides changing the ways in which the society functions, these technologies are also changing its basic structures. Thus the information society brings with it a radical social and political transformation.

The new socio-political reality might be represented by electronic democracy (e-democracy). Some see it as the solution of all the modern democratic problems and in some areas it might also represent an answer to the shortcomings of socio-political structures in developed western countries, as exposed by the current economical crisis.

The Slovenian eAdministration Strategy (SEP-2010) is currently the central document on e-democracy in Slovenia. In the future, the Strategy on IT and electronic services development and connection of official records (SREP), will probably take its place. At least for the near future, the development of e-democracy in Slovenia will be linked to the development of e-administration. The purpose of this article is to highlight the position of e-democracy in Slovenia using an analysis of SEP-2010 and commentaries on SREP. It will also try to confirm the thesis that the Republic of Slovenia needs a specific document and strategy in order to reach the set goals in the area of e-democracy and ensure its further development.

Steven Clift describes e-democracy as the way the internet can reinforce the existing democratic processes and enhance the possibilities of interaction between individuals/groups and the people in charge of decision making, which enables the latter to gain more input and insight into the wishes and demands of the former. He feels that the internet offers to the e-democracy new possibilities of communication and participation between the citizens and the state. Another important part of e-democracy 
Andraž Bobovnik

E-demokracija v Sloveniji: analiza strategij E-uprave

is also the aspect of democratic institutions, decision making processes, the representation of interests in organisation etc. Tanja Oblak writes on the subject:" Judging from previous experience e-democracy is not a project which competes with the existing democratic systems but rather it is compatible with several different existing institutions and in practice it is usually conceived in a way that compensates for their obvious shortcomings. E-democracy does not represent a new form of democracy but the adaptation of existing forms to new circumstances".

On April $20^{\text {th }} 2006$, the Slovene government accepted the Slovenian eAdministration Strategy, with the objective to identify the means and the goals for further implementation of e-administration activities. The Strategy represents the vision of e-administration, the influences of other domestic and foreign strategies and programmes in this field, the condition assessment for the previous period, the strategic outlines and goals for 2010 and the conditions for implementing the set strategies. The emphasis is on user satisfaction, the rationalisation of administrative practices and on modern electronic services which will enable a higher quality of living and easier communication with the public administration bodies.

The analytical criteria have been divided into two sets: the actors and the implementation of SEP-2010. The area of actors has been further divided into two parts. The first part focuses on the positioning of the key actors in SEP-2010 and the question of how informed they are, while the second part focuses on their participation. In the area of participation the analysis is divided into three parts: the instruments of e-democracy, the institutional changes and the evaluation of the strategy.

The analysis of SEP-2010 shows that the strategy employs key actors as citizens and does not make provisions for additional activities regarding the information available to them; does not deal with marginalised and underprivileged individuals and groups; does not take specific initiatives in the field of minimising the digital divide; presupposes citizen participation only in the first two phases of developing and implementing public policies; limits citizen participation to informing and consulting; mentions only in passing the instruments of e-democracy; pays no attention to new institutional and process approaches and forms of e-democracy.

In its $34^{\text {th }}$ regular session on July $2^{\text {nd }} 2009$, the Government of the Republic of Slovenia discussed and approved the Strategy on IT and electronic services development and connection of official records. The purpose of the new strategy in the field of e-administration is the definition of 
the framework and the goals for further implementation of new and already set activities of the development of electronic services in public administration.

In SREP E-democracy is only mentioned four times and never as a central notion. It is not recognised in SREP as an integral part of the development of the information society in Slovenia or as one of its primary goals. Despite the fact that the strategy is based on domestic and foreign documents the goal of which is also change in the socio-political arena, SREP seems not to embrace that goal. E-democracy as one of the central notions of the information society is thus left out of the context of the Strategy on IT and electronic services development and connection of official records.

The Slovenian e-Administration Strategy and the Strategy on IT and electronic services development and connection of official records are the first and foremost strategic documents covering the field of eadministration. However, the absence of any other more specific document in this field suggests that they will have an unquestionable effect on the further development of e-democracy in Slovenia. SEP-2010, in the chapter Outlines and goals until 2010, even states: "Slovenia (in 2010) is one of the most developed countries in the world regarding edemocracy".

The index of e-participation in the UN report on the general state of eadministration in 192 countries for the year 2007 ranks Slovenia in the $60^{\text {th }}$ place, the same report for the year 2005 ranks it as $46^{\text {th }}$. The development of e-democracy in Slovenia seems to have been slowed down compared to other countries. And even though the indexes which show exclusively the development of e-administration tend to rank Slovenia relatively high, the ranking falls considerably when e-participation is considered as one of the key elements of e-democracy.

The analysis of SEP-2010 and the commentary on SREP clearly show that both strategies fail to fulfil the basic conditions for the successful development of e-democracy in Slovenia. We can therefore maintain with considerable certainty that the Republic of Slovenia needs a specific document and strategy in order to reach the set goals and ensure the proper development of e-democracy. A suitable start would be a strategic document which would shift the development of e-democracy in Slovenia from the position of a legalistic model of democracy where the information communication technologies only address the issue of providing 
Andraž Bobovnik

E-demokracija v Sloveniji: analiza strategij E-uprave

information, towards the participative model of democracy which would upgrade providing information to citizens with one of the tools which encourage the participation of citizens as well as deliberation in the democratic processes. Such a basis would enable further development of decision making tools of e-democracy as well as a true participation of citizens in the decision making processes, which after all represents the very essence of e-democracy. 